\title{
Salicylic acid and ascorbic acid retrieve activity of antioxidative enzymes and structure of Caralluma tuberculata calli on PEG stress
}

\author{
Riaz U. Rehman ${ }^{1}$, Muhammad Zia ${ }^{2}$ and Muhammad F. Chaudhary ${ }^{3}$ \\ ${ }^{1}$ Horticulture and Floriculture Institute, Government of Punjab, Rawalpindi, Pakistan \\ ${ }^{2}$ Department of Biotechnology, Quaid-i-Azam University, Islamabad, Pakistan \\ ${ }^{3}$ Preston Institute of Nanoscience and Technology, Preston University, Islamabad, Pakistan
}

\begin{abstract}
Biochemical adaptations and morphological changes are cellular aptitude originated on biotic and abiotic stresses. Polyethylene glycol (PEG) induces drought stress in the nutrient solution. In the present investigation, Caralluma tuberculata calli is exposed to PEG and antioxidative molecules. By increasing the level of antioxidative enzymes (SOD, POD, CAT, APX, and GR), the PEG-stressed calli falls off upon exposure to non-enzymatic antioxidants (ascorbic acid and salicylic acid). Under PEG-stress, several cellular and sub-cellular changes such as alteration in plasma membrane thickness, change in nucleus shape, increase in nucleoli, deformation of thylakoid membranes, and increase in plastoglobuli are observed through electron microscopic images. From our results we conclude that application of PEG (a drought causative agent) leads to an increase in the level of antioxidative enzymes and also deformation of cellular organelles. However, application of ascorbic acid and salicylic acid eradicate drought effect induced by PEG.
\end{abstract}

Key words: Antioxidant enzymes - Caralluma tuberculata calli - PEG stress - ROS - Ultrastructure

\section{Introduction}

Several environmental factors (e.g., drought, salinity, temperature, pollution etc.) above their threshold level adversely affect the growth, metabolism and yield of plants. The plant experience drought when the water supply to root is limited or transpiration rate is high compared to water uptake. All plants have drought-resistant mechanisms but resistance level varies specie to specie. The general effects of drought and abiotic stresses are well known; however, at cellular levels not well understood (Rehman et al. 2014a). In order to improve the plant productivity within the limited land resources, it is necessary to investigate cellular behavior against environmental stresses. Understanding the cell response to drought stress is of greater importance to make the plant to tolerate the stress. Considerable change in water and ionic balance lead to damage at molecular level and se-

Correspondence to: Muhammad Zia, Department of Biotechnology, Quaid-i-Azam University, Islamabad, Pakistan 45320

E-mail: ziachaudhary@gmail.com verely affecting the growth of stressed plants. Consequently, the plant tissues die, resulting plant death in severe conditions (Xiong and Zhu 2002). These stresses also resulted in the interference in growth and metabolism triggered by secondary responses, e.g., the production of highly reactive oxygen species (ROS). ROS although constantly produces in the cells because they function as signals; mediators in different biochemical pathways, defense against stresses and polymerization of cell wall constituents. However, production and scavenging potential is disturbed when plant cells are under stress. To control this imbalance for proper metabolism, growth, maintenance, and stress tolerance both low molecular weight antioxidants and antioxidative enzymes are required (Foyer and Noctor 2005). The production of ROS such as the hydrogen peroxide $\left(\mathrm{H}_{2} \mathrm{O}_{2}\right)$, superoxide radical $\left(\mathrm{O}^{-2}\right)$, and the hydroxyl radical $\left(\mathrm{OH}^{-1}\right)$ are critical because they not only interfere biochemical reactions but also cause changes in the cellular structure. The major antioxidative enzymes are superoxide dismutase (SOD) catalyzing the dismutation of $\mathrm{O}^{-2}$ to $\mathrm{H}_{2} \mathrm{O}_{2}$; catalase (CAT) that dismutase $\mathrm{H}_{2} \mathrm{O}_{2}$ to oxygen and water and ascorbate peroxidase (APX) 
that reduces $\mathrm{H}_{2} \mathrm{O}_{2}$ to water by using ascorbate as particular electron donor. Other enzymes are glutathione reductase (GR), monodehydroascorbate reductase (MDHAR), dehydroascorbate reductase (DHAR), glutathione peroxidase (GPX), and glutathione-D-transferase which significantly play role in protecting cell against oxidative stress (Foyer and Noctor 2005).

Previous reports showed that in plants drought induces accumulation of the superoxide anion radical, hydrogen peroxide and hydroxyl radicals. The accumulated radicals can be lethal, leading to cell death. For polymerization of phenoxyl radicals, $\mathrm{H}_{2} \mathrm{O}_{2}$ is provided through the oxidative peroxidase activity which mediates the reduction of $\mathrm{O}_{2}$ to superoxide anion radicals (Almagro et al. 2009). In cell/plants physiological changes takes place under draught condition. This might be due to dehydration at cellular level, swelling and structural collapse of membranes, disorder of the outer chloroplast envelope, thinning of partitions, adhesion within the grana and decrease in chloroplast volume. However, swelling of thylakoids has not been observed on polyethylene glycol (PEG) treatment (Yamane et al. 2003; Türkan et al. 2005).

The two water-soluble antioxidant molecules, i.e., salicylic acid (SA) and ascorbic acid (AA) serve as detoxificant for hydrogen peroxide in a cyclic pathway. Consistent findings reported the effect of AA, exogenously applied to improve the adverse effects on growth due to stresses (Mozafar and Oertli 1992). SA also intervenes the oxidative rupture that causes cell death in an oversensitive reaction and proceeded as a signal to develop complete internal resistance (Shirasu et al. 1997). It also plays an important role in many abiotic stresses, leading to the survival of plants against these pressures (Senaratna et al. 2000). Unexpectedly, little is reported to signify the role of these antioxidative compounds in callus stress adaptation. The main aim of the present study is to investigate the role of antioxidative enzymes in the callus growth of Caralluma tuberculata under drought stress caused by PEG. Further, an increase in PEG-stress caused by AA and SA as well as intracellular changes resulted by the stress in callus tissues of $C$. tuberculata is also investigated. The study will be helpful to understand the biochemical and cellular changes taking place in undifferentiated mass of cells compared to tissues reported in the literature.

\section{Materials and Methods}

\section{Plant material and explant preparation}

The plant (C. tuberculata) material was obtained from Quetta (Balochistan, Pakistan) and is identified by taxonomist Department of Plant Sciences, Quaid-i-Azam University Islamabad, Pakistan. The methodology to produce callus is adopted as described by Rehman et al. (2014b). Briefly, the stem portions are treated with water, following $0.2 \%$ Triton $\mathrm{X} 100$ and finally with bevistin. After rinsing with distilled water, plant material is disinfected with $0.1 \% \mathrm{HgCl}_{2}$ solution under aseptic conditions. Thereafter, the shoot tip portion ( $\sim 10 \mathrm{~mm}$ long) is isolated aseptically and cultured on MS medium.

The MS (Murashige and Skoog 1962) medium supplemented with 6-benzyl amino purine $(4.44 \mu \mathrm{M})$ and 2,4-dichloro-phenoxy acetic acid $(9.04 \mu \mathrm{M})$ along with thidiazuron $(9.08 \mu \mathrm{M})$ is employed to induce callus from shoot tip explants of C. tuberculata. Sucrose (3\%) is added as carbon source and $\mathrm{pH}$ is adjusted at $5.7 \pm 0.1$. The media is solidified with $0.7 \%$ Noble agar (Merck) and autoclaved. All the cultures are maintained in culture room at $25 \pm 2{ }^{\circ} \mathrm{C}$ and 3500 lux light intensity using $16 \mathrm{~h}$ light photoperiod.

After 28 days of initiation of calli, small pieces (approx. $1 \mathrm{~g}$ ) are transferred on plant growth regulators supplemented MS medium along with different concentrations of PEG (50-200 g/l). To analyze the effect of stress alleviators, calli are transferred on MS medium containing $200 \mathrm{~g} / \mathrm{l}$ PEG with 100 and $200 \mu \mathrm{M}$ AA or SA for 15 days. The weight of callus is measured before and after the application of PEG alone and in combination of antioxidants. The change in fresh weight is calculated in percentage.

\section{Determination of antioxidative enzymes activities}

To determine the antioxidative enzymes activities, callus is grinded in chilled mortar and pestle with homogenization buffer. The homogenized callus is centrifuged at $10000 \times g$ for $20 \mathrm{~min}$ at $4^{\circ} \mathrm{C}$. Supernatant is used to determine enzymes activities and protein contents.

Superoxide dismutase (SOD; EC 1.15.1.1) activity is assayed by using the photochemical NBT (nitro blue tetrazolium) method (Zhou et al. 1997). The sample $(0.5 \mathrm{~g})$ is homogenized in $5.0 \mathrm{ml}$ extraction buffer consisting of $50.0 \mathrm{mM}$ phosphate buffer ( $\mathrm{pH} 7.8)$. The assay mixture $(3.0 \mathrm{ml})$ contains $50.0 \mathrm{mM}$ phosphate buffer $(\mathrm{pH}$ 7.8), $1.0 \mu \mathrm{M}$ EDTA, 26.0 mM L-methionine, $750.0 \mu \mathrm{M}$ $\mathrm{NBT}$ and $20.0 \mu \mathrm{M}$ riboflavin. The photo-reduction (formation of purple formazan) of NBT is measured at $560 \mathrm{~nm}$ through spectrophotometer and an inhibition curve is made against different volumes of extract. One unit of SOD is defined as the volume of extract present in reaction mixture that causes inhibition of the photoreduction of NBT by $50 \%$.

Volume of $3.0 \mathrm{ml}$ guaiacol is used as a substrate to measure the peroxidase (POD; EC 1.11.1.7) activity. A reaction mixture is constituted by mixing of $1 \%$ guaiacol, $0.4 \% \mathrm{H}_{2} \mathrm{O}_{2}, 50.0 \mathrm{mM}$ potassium phosphate buffer $(\mathrm{pH}$ 6.1) and enzyme extract. Guaiacol oxidation and increase in absorbance is measured at $470 \mathrm{~nm}$ through spectropho- 
tometer. Activity of the enzyme is found at $25 \pm 2{ }^{\circ} \mathrm{C}$ in $\mu \mathrm{M}$ of guaiacol oxidized $\mathrm{min}^{-1} \mathrm{~g}^{-1}$ fresh weight (Nakano and Asada 1981).

The assay for ascorbate peroxidase (APX; EC 1.11.1.11) activity is carried out according to the method of Nakano and Asada (1981). In a reaction mixture $(3.0 \mathrm{ml})$ containing $100.0 \mu$ l enzyme extract, $100.0 \mathrm{mM}$ phosphate buffer $(\mathrm{pH}$ 7), $0.3 \mathrm{mM}$ ascorbic acid, $0.1 \mathrm{mM}$ EDTA- $\mathrm{Na}_{2}$ and $0.06 \mathrm{mM}$ $\mathrm{H}_{2} \mathrm{O}_{2}$. In this reaction mixture $\mathrm{H}_{2} \mathrm{O}_{2}$ is added and after $30 \mathrm{~s}$ of this addition, the change in absorption is recorded at $290 \mathrm{~nm}$.

To determine catalase (CAT; EC 1.11.1.6) activity, $25.0 \mathrm{mM}$ buffer of potassium phosphate containing $0.1 \mathrm{mM}$ EDTA ( $\mathrm{pH} 7.0$ ) is mixed with $10.0 \mathrm{mM} \mathrm{H}_{2} \mathrm{O}_{2}$ and enzyme extract (Pine et al. 1984). Within one min of enzyme extract mixing, the reduction in the absorbance of $\mathrm{H}_{2} \mathrm{O}_{2}(\mathrm{E}=$ $\left.39.4 \mathrm{mM}^{-1} \mathrm{~cm}^{-1}\right)$ is recorded at $240 \mathrm{~nm}$ on spectrophotometer.

Glutathione reductase (GR; EC 1.6.4.2) activity is determined by the method reported by Foyer and Halliwell (1976). Reduction in absorbance is monitored at $340 \mathrm{~nm}$. This decrease in absorbance is due to the oxidation of NA$\mathrm{DPH}\left(\mathrm{E}=6.2 \mathrm{mM}^{-1} \mathrm{~cm}^{-1}\right)$. The reaction is carried out by mixing $25.0 \mathrm{mM}$ potassium phosphate buffer. This buffer is formulated at pH 7.8 by the addition of $0.2 \mathrm{mM}$ EDTA. Enzyme aliquot is added to record the absorbance.

Total soluble protein in extract is determined by using the method described by Bradford (1976).

\section{Transmission electron microscopy of treated calli}

Calli $\left(2-3 \mathrm{~mm}^{2}\right)$ are fixed in $2.5 \%$ glutaraldehyde at room temperature in $0.1 \mathrm{M}$ sodium phosphate buffer ( $\mathrm{pH}$ 7.4) and rinsed three times with same buffer. The washed callus samples are post fixed in $1 \%$ osmium (VIII) oxide $\left(\mathrm{OsO}_{4}\right)$ for $1 \mathrm{~h}$. Then the samples are thoroughly washed with buffer and dipped for 15-20 min interval in a graded ethanol series $(50,60,70,80,90,95$, and $100 \%)$. Finally, the samples are dipped for $20 \mathrm{~min}$ in absolute acetone. The samples are then penetrated and implanted in Spurr's resin for whole night. The specimen is heated at $70^{\circ} \mathrm{C}$ for $9 \mathrm{~h}$ to prepare very slim cuttings $(80 \mathrm{~nm})$ of the specimens. Copper grids are used to mount these ultra-thin specimens (Leica EM UC7) for screening at $20000 \times$ in the transmission electron microscope (JEOL TEM-1230EX) at an accelerating voltage of $60.0 \mathrm{kV}$.

\section{Data analysis}

Percent variation of the growth protein content and antioxidant enzymes is calculated as follow:

$\%$ variation $($ for PEG stress $)=(($ value for treated calli untreated calli)/untreated calli) $\times 100$
$\%$ variation (for mitigants $)=(($ value of treated calli - calli at $200 \mathrm{~g} / \mathrm{l} \mathrm{PEG}) /$ calli at $200 \mathrm{~g} / \mathrm{l} \mathrm{PEG}) \times 100$

All the experiments are performed in triplicate and the results are presented as mean \pm standard error (SE). The values are analyzed by LSD test with $p<0.05$. Analysis of variance (ANOVA) was performed to compare the means.

\section{Results and Discussion}

\section{Growth kinetics and antioxidative enzymes pattern}

The fresh weight of C. tuberculata calli is gradually decreased by increasing the PEG concentrations in the culture media. In the presence of PEG, an increase in the antioxidative enzymes in the calli is noticed. Conversely, incorporation of SA and AA in the medium reverted the cells under normal condition.

Using $50 \mathrm{~g} / \mathrm{l} \mathrm{PEG}$ and $200 \mathrm{~g} / \mathrm{l}$ of PEG in callus culture media resulted in $16.3 \%$ and $40.2 \%$ decrease in fresh weight, respectively (Table 1 ). Moreover, the total soluble protein content is decreased to $41.2 \%$ at 50 and $100 \mathrm{~g} / \mathrm{l} \mathrm{PEG}$, while at $200 \mathrm{~g} / \mathrm{l}$ we have noticed a further decrease (19.7\%) in the weight of PEG-treated calli. In the presence of PEG, the cells in C. tuberculata calli are generated in compact way. The previously reported studies showed that cellular dehydration decreased the packed cell volume due to inflammation and structural collapse. The proteins responsible for osmotic balance and signaling pathway, specifically suppressed due to salt stress, leading to reduction in the soluble protein contents (Zhu 2001; Queirós et al. 2011). With the addition of SA and AA antagonized the negative effects of drought stress on callus growth. AA and SA at higher concentration $(200 \mu \mathrm{M})$ also promoted the growth

Table 1. Effects of PEG and antioxidant treatments on fresh weight and total soluble protein of Caralluma tubarculata calli

\begin{tabular}{lcc}
\hline Treatment & $\begin{array}{c}\text { Fresh weight } \\
(\mathrm{g})\end{array}$ & $\begin{array}{c}\text { Total soluble protein } \\
(\mathrm{mg} / \mathrm{g} \mathrm{FW})\end{array}$ \\
\hline Control & $20.7 \pm 0.9^{\mathrm{b}}$ & $1.37 \pm 0.4^{\mathrm{c}}$ \\
PEG 50 g/l & $17.2 \pm 0.6^{\mathrm{c}}$ & $0.97 \pm 0.21^{\mathrm{f}}$ \\
PEG 100 g/l & $14.6 \pm 1.1^{\mathrm{e}}$ & $0.97 \pm 0.18^{\mathrm{f}}$ \\
PEG 200 g/l & $12.4 \pm 0.8^{\mathrm{f}}$ & $1.1 \pm 0.4^{\mathrm{e}}$ \\
PEG 200 g/l + AA 100 $\mu \mathrm{M}$ & $15 \pm 0.9^{\mathrm{d}, \mathrm{e}}$ & $1.24 \pm 0.4^{\mathrm{d}}$ \\
PEG 200 g/l + AA 200 $\mu \mathrm{M}$ & $17.2 \pm 0.7^{\mathrm{c}}$ & $5.36 \pm 0.6^{\mathrm{a}, \mathrm{b}}$ \\
PEG 200 g/l + SA 100 $\mu \mathrm{M}$ & $15.8 \pm 0.6^{\mathrm{d}, \mathrm{e}}$ & $4.67 \pm 0.4^{\mathrm{b}}$ \\
PEG 200 g/l + AA 200 $\mu \mathrm{M}$ & $25.1 \pm 1.0^{\mathrm{a}}$ & $5.93 \pm 0.6^{\mathrm{a}}$ \\
\hline
\end{tabular}

The results are presented as average \pm standard deviation. Means followed by same small letters are not significantly different by the LSD test at $p \leq 0.05$. AA, ascorbic acid; SA, salicylic acid; PEG, polyethylene glycol. 


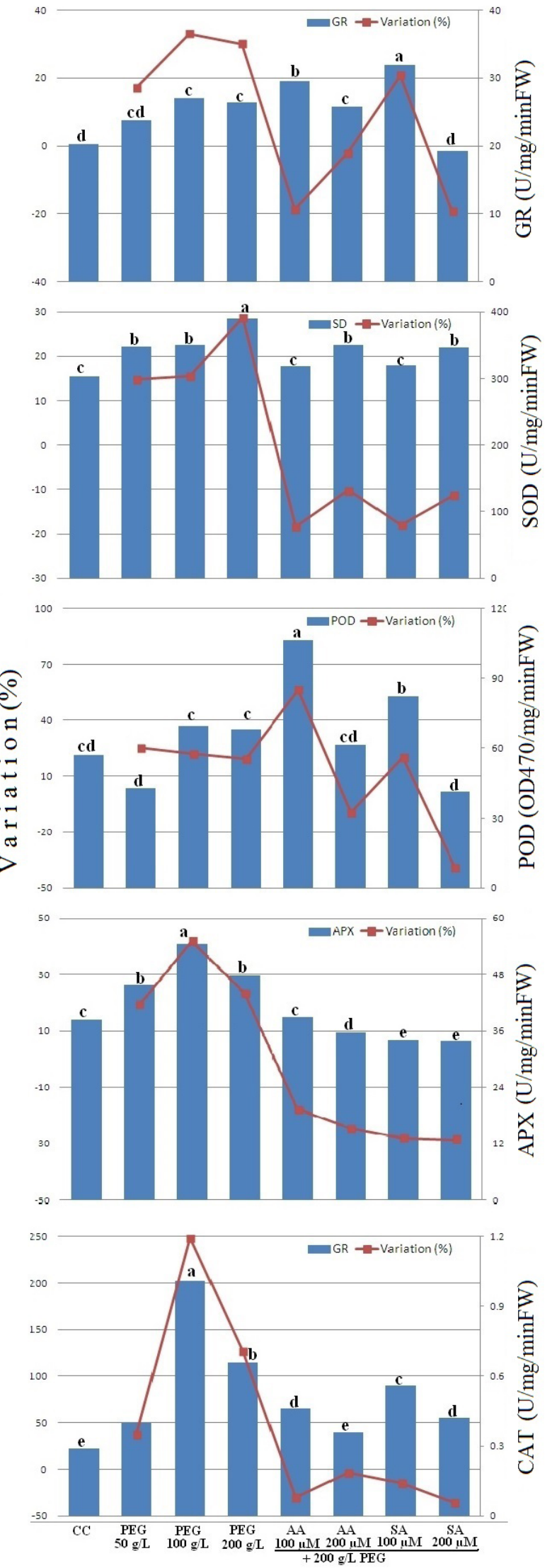

rate compared to unstressed calli (control). Therefore, the fresh weight is increased to $40.6 \%$ and $102.4 \%$ on culturing the calli in the presence of $200 \mu \mathrm{M}$ AA and SA along with 200 g/l PEG, respectively (Table 1). These non-enzymatic antioxidants (SA and AA) are important for plant growth and development along with antioxidant capacity (Barth et al. 2006). SA also acted as a signal due to origination of internal resistance of the plant against biotic and abiotic stresses. Drought stress due to PEG had negative effect on total soluble protein contents, resulting significant reduction in stressed calli. However, compared to control and stressed calli, a significant increase in protein contents is observed with the addition of antioxidants. SA proved comparatively good for protein contents of C. tuberculata callus exhibiting significant increase in the value of protein content $(5.93 \mathrm{mg} / \mathrm{g} \mathrm{FW}$; 332\% increase as compared to $200 \mathrm{~g} / \mathrm{l} \mathrm{PEG}$ stressed calli) at $200 \mu \mathrm{M}$. The non-enzymatic antioxidants provided shield against oxidative burst and also stimulated the biomass accumulation, leading to increase in fresh and dry weight (Kováčik et al. 2009).

The calli grown in the presence of PEG exhibited different antioxidative enzymes response by increasing PEG concentration in the culture media, a boost in oxidative enzymes levels is noticed in the calli. A maximum increase of $28.7 \%$ is observed in SOD in the calli grown at $200 \mathrm{~g} / \mathrm{l}$ PEG concentration (Figure 1). However, for case of GR, POD, APX and CAT higher activities are observed at $100 \mathrm{~g} / \mathrm{l}$ PEG compared to $200 \mathrm{~g} / \mathrm{l}$. Maximum increase of $244.8 \%$ in CAT is calculated in the calli multiplied at $100 \mathrm{~g} / \mathrm{l}$ PEG. Concentrations of these enzymes decreased when AA and SA were also applied in combination with 200 g/l PEG. Except SOD, the reduction is more pronounced by applying $200 \mu \mathrm{M}$ compared to $100 \mu \mathrm{M}$. A total of 18.4 and $17.9 \%$ decrease in SOD is observed at $100 \mu \mathrm{M}$ AA and SA, respectively, while this decrease is 10.2 and $11.2 \%$ at $200 \mu \mathrm{M}$ of both antioxidants. Interestingly, POD level is $56.3 \%$ and $20.4 \%$ increase in the POD level is observed in the calli grown at $100 \mu \mathrm{M}$ of AA and SA compared with control (calli grown at $200 \mathrm{~g} / \mathrm{l} \mathrm{PEG),} \mathrm{respectively.} \mathrm{Similarly,} \mathrm{for} \mathrm{the}$ case of GR, $200 \mu \mathrm{M}$ of antioxidant is effective to mitigate water stress. Increase in SOD activity has been reported upon drought stress in tobacco, wheat and pea. Osmotic stress induces an increase in APX and SOD activities in rape plant leaves as compared to control. Increased activities

Figure 1. Effects of drought caused PEG and anti-oxidants on GR, SOD, POD, APX and CAT activities in Caralluma tubarculata calli. Data are the mean \pm S.D. of three replicates. Small letters marked on each bar are not significantly different by the LSD test at $p \leq 0.05$. CC, control calli; AA, ascorbic acid; APX, ascorbate peroxidase; CAT, catalase; PEG, polyethylene glycol; POD, peroxidase; SA, salicylic acid; SOD, superoxide dismutase. 
of GR, SOD and APX have also been recorded in drought tolerant wheat cultivar (Lascano et al. 2001).

The drought stress changed the salinity level. Eventually, this induces hypersensitivity reaction, leading to cell death. To avoid this situation, SA serves as protecting agent through activation APX enzymes and aldose reductase by the accumulation of alcohol, proline or sugars as osmolytes (Szepesi et al. 2005). The increase in APX activity has also been reported in alfalfa plant even in stress-tolerant cultivar under PEG treatment (Wang et al. 2009). In drought tolerant tomatoes, an increase in the concentration of APX can be linked with lower peroxidation of lipid (Türkan et al. 2005). The similar effects have also been noticed in rice plants and sugar beet (Demiral and Türkan 2005). The increase in APX activity indicated that the treatment of drought lead to oxidative stress.

Drought and/or osmotic stresses lead to significant increase of ROS in plant cells. SOD, CAT and POD are major affiliate to scavenge ROS both via enzymatic and non-enzymatic mechanisms. However, environmental stimuli such as light, temperature, water and others are also responsible to stimulate these mechanisms (Faria et al. 1996). In the absence of a proper scavenging capability, cellular structures and macromolecules including DNA can be significantly damage. Following oxidative damage in DNA, cells are characterized by the activity of nucleases involved in repair process (Roldán-Arjona and Ariza 2009). Previously reported studies showed that under drought stress the activity of anti-oxidative enzymes changes dramatically in seedlings and the MDA content strongly increase, leading to insufficient water supply which causes significant adverse effects on seedling growth and development (Habib et al. 2013).

Ultra-structural analysis of calli upon PEG and antioxidant treatment

Ultra-structural observations of Caralluma cell showed the modifications in PEG-treated cells which are more pronounced in cell wall, nucleus and plastids. The cell wall of the untreated callus cells is thick and granular cytoplasm with densely packed numerous sub-cellular
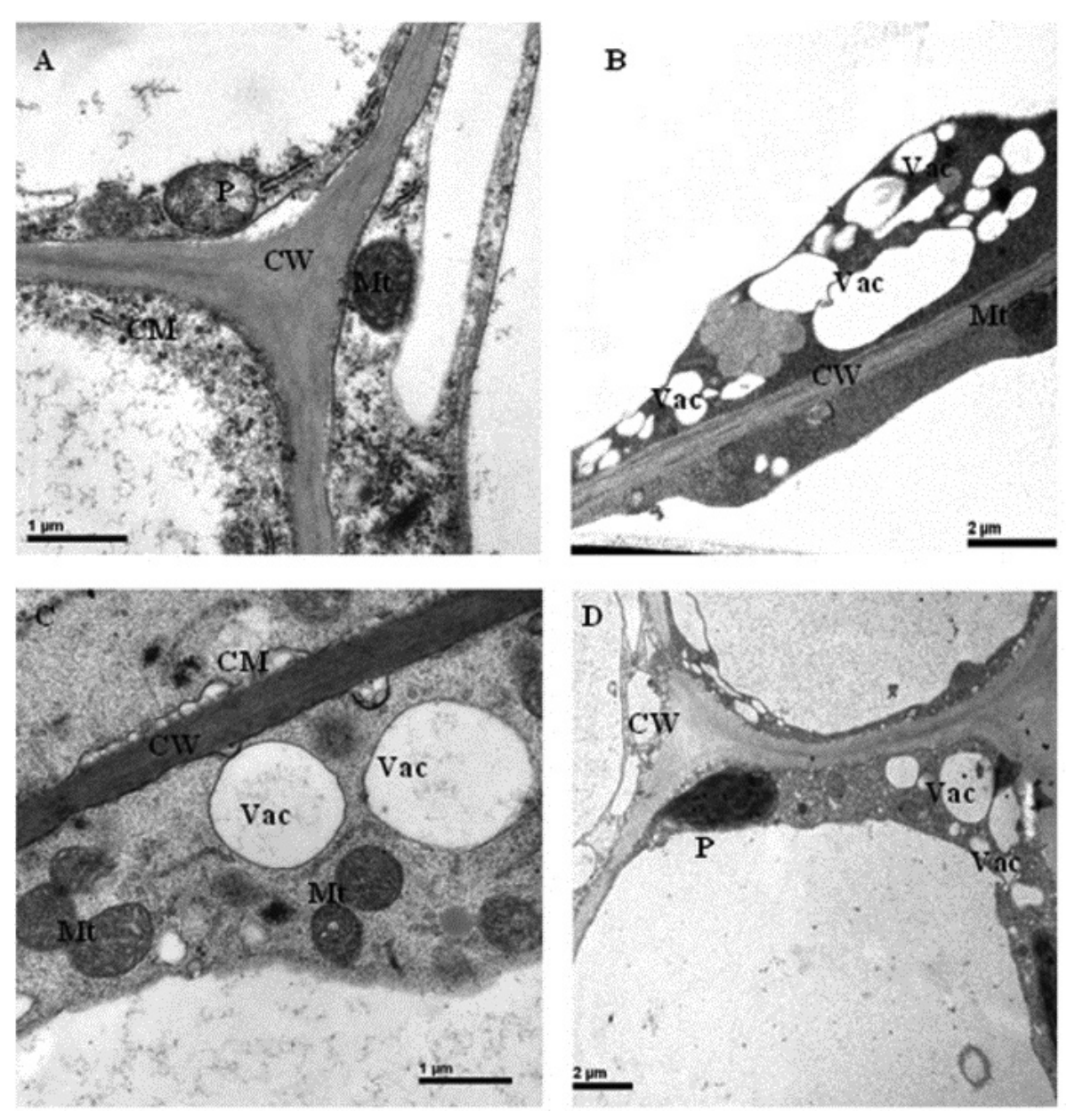

Figure 2. Electron micrographs of Caralluma tuberculata calli describing modifications in cell wall, cell membrane and vacuoles: control (A), exposed to $200 \mathrm{~g} / \mathrm{l} \mathrm{PEG}$ alone (B), exposed to $200 \mathrm{~g} / \mathrm{l} \mathrm{PEG}$ + ascorbic acid $(200 \mu \mathrm{M})(\mathbf{C})$, exposed to $200 \mathrm{~g} / \mathrm{l} \mathrm{PEG}+$ salicylic acid $(200 \mu \mathrm{M})(\mathrm{D})$. CW, cell wall; CM, cell membrane; Mt, mitochondria; P, plastid; Vac, vacuole; PEG, polyethylene glycol. 

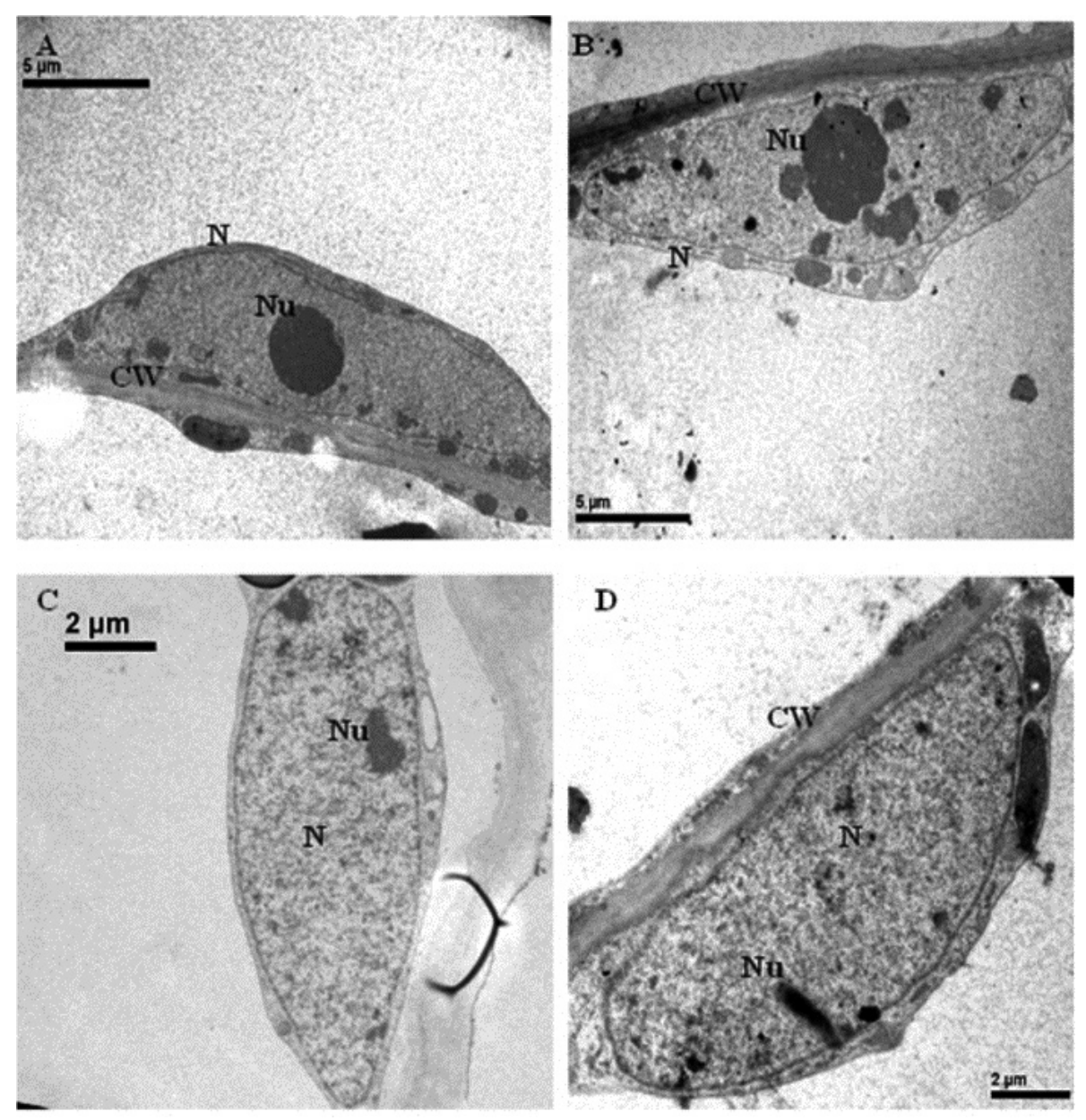

Figure 3. Electron micrographs of Caralluma tuberculata calli describing variations in nucleus control (A), exposed to $200 \mathrm{~g} / \mathrm{l} \mathrm{PEG}$ alone (B), exposed to $200 \mathrm{~g} / \mathrm{l} \mathrm{PEG}+$ ascorbic acid $(200 \mu \mathrm{M})(\mathrm{C})$, exposed to $200 \mathrm{~g} / \mathrm{l} \mathrm{PEG}+$ salicylic acid $(200 \mu \mathrm{M})$ (D). CW, cell wall; $\mathrm{N}$, nucleus; $\mathrm{Nu}$, nucleolus; PEG, polyethylene glycol. organelles (Fig. 2A). These untreated cells contain smooth, clean and continuous cell membranes, central vacuole, well shaped nucleus (Fig. 3A), few mitochondria and plastids (Fig. 4A). A substantial reduction in the cell wall thickness due to changes in cell wall and cell membrane under PEG stress (Fig. 2B). Drought stress leads to modification in nucleus with triangular in shape having more nucleoli (Fig. 3B). The plastids of PEG-treated cells contain more plastoglobuli, very low grana, fragmented stroma thylakoids, and starch inclusions (Fig. 4B). On AA with PEG treatment, cell wall becomes relatively good in shape, however, number of vacuoles is increased (Fig. $2 \mathrm{C}$ ), this exhibiting a positive effect on the plastids and nucleus (Fig. 2C). Plastids are oval to oblong in shape. The internal membrane system is more compact with high grana connected with long stroma thylakoids, although, several plastoglobuli are observed (Fig. 4C). On the other hand, with the addition of SA, structure of cellular organelles is reshaped much similar to untreated control cells. Thylakoid membranes and shape of plastids also restored as well (Fig. 4D).
The starch granules originated on PEG treatment also normalized on AA and SA application. Water stress often disrupts the chloroplast structure. Chloroplasts showed some breakdown of thylakoid structure. Stress causes the swelling of thylakoids while plastoglobuli indicate disturbed the lipid metabolism might be due to the accumulation of abundant lipids (Ackerson and Herbert 1981; Soikkeli 1981; Holopainen et al. 1992). Inhibitions of chloroplast membrane under low leaf water potentials and changes in cells of water-stressed leaves have already been reported. Cells from stressed plants have significantly reduced fractional volume of cytoplasm and increased fractional volume of central vacuole (Berlin et al. 1982). Higher PEG concentration induces ultra morphological changes, leading to increase the number of vacuoles and nucleoli in C. tuberculata. Production of many mitochondria lead to an increase in energy requirement of the cell required to alleviate the drought stress. Similarly higher number of nucleoli seems to be enhancing the mRNA, ribosomes production and new proteins synthesis involved in the tolerance of the plant against stress (Sresty and Rao 1999). 

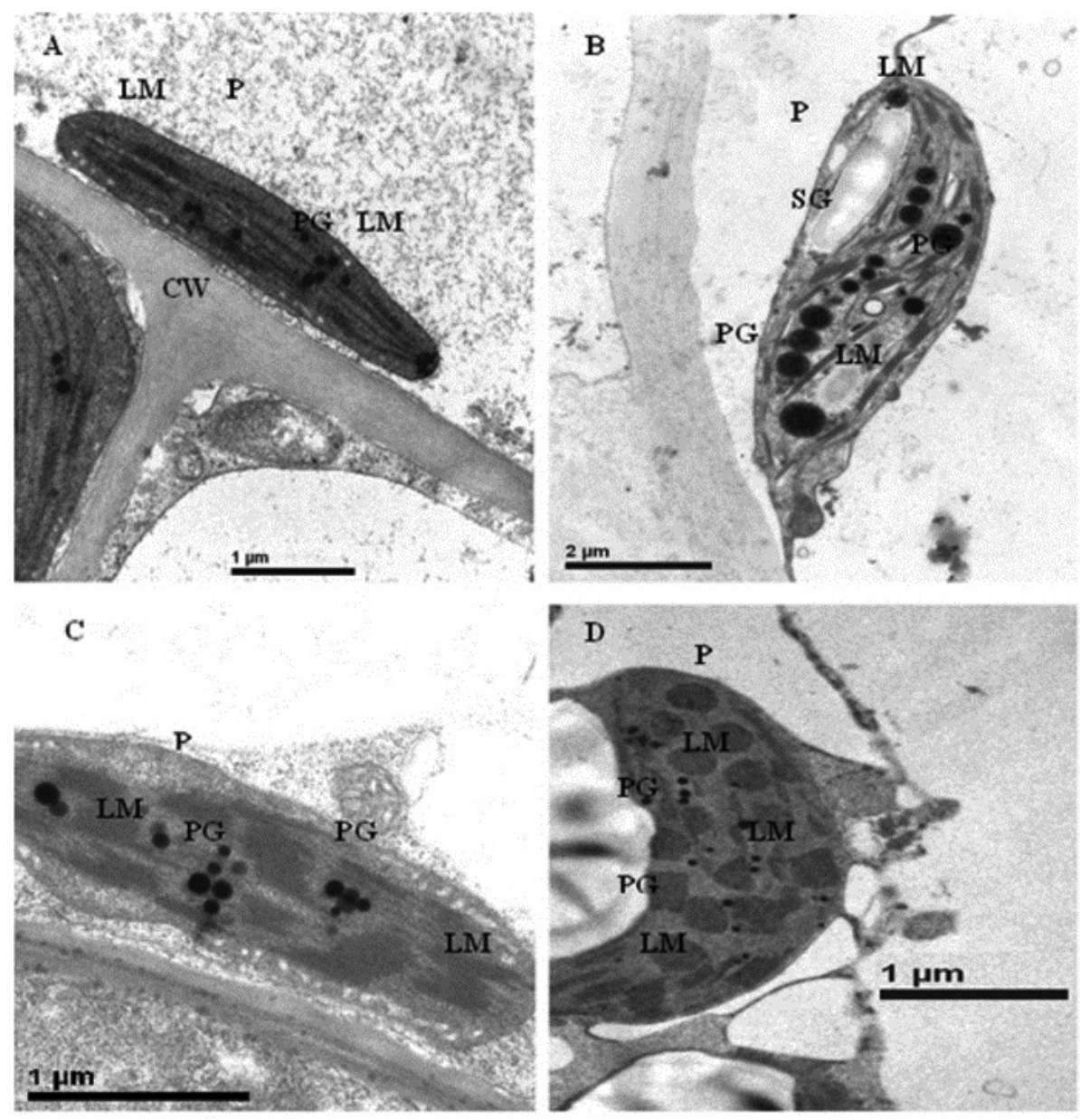

Figure 4. Electron micrographs of Caralluma tuberculata calli describing variations in plastids: control (A), exposed to $200 \mathrm{~g} / \mathrm{l}$ PEG alone (B), exposed to $200 \mathrm{~g} / \mathrm{l} \mathrm{PEG}+$ ascorbic acid $(200 \mu \mathrm{M})(\mathrm{C})$, exposed to $200 \mathrm{~g} / \mathrm{l}$ PEG + salicylic acid $(200 \mu \mathrm{M})$ (D). CW, cell wall; CM, cell membrane; P, plastid; PG, plastoglobuli; LM, thylakoid membrane; PEG, polyethylene glycol.

\section{Conclusions}

In conclusion, the antioxidative enzymes (SOD, CAT, GR, POD and APX) play a vital role in the calli of Caralluma tuberculata to tolerate drought condition due to the incorporation of PEG in the culture medium. Presence of PEG also resulted in the cellular disintegration expressed at cell membrane, nuclear membrane, nucleoli number, and plastids. The antioxidant molecules (SA and AA) effectively mitigated PEG toxicity and enhanced the growth of C. tuberculata calli showed by normal circulation of antioxidative enzymes and restoration of cell structure.

Conflict of interest. Authors declare no conflict of interest.

\section{References}

Ackerson R. C., Herbert R. R. (1981): Osmoregulation in cotton in response to water stress. 1 . Alterations in photosynthesis leaf conductance translocation and ultrastructure. Plant Physiol. $67484-488$ https://doi.org/10.1104/pp.67.3.484

Almagro L., Ros L. V. G., Belchi-Navarro S., Bru R., Barceló A. R., Pedre-o M. A. (2009): Class III peroxidases in plant defence reactions. J. Exp. Bot. 60, 377-390 https://doi.org/10.1093/jxb/ern277

Barth C., De Tullio M., Conklin P. L. (2006): The role of ascorbic acid in the control of flowering time and the onset of senescence J. Exp. Bot. 57, 1657-1665 https://doi.org/10.1093/jxb/erj198

Berlin J., Quisenberry J. E. B., Woodworth M. F., Mcmichael B. L. (1982): Effect of water stress on cotton leaves I. An electron microscopic stereological study of the palisade cells. Plant Physiol. 70, 238-243 https://doi.org/10.1104/pp.70.1.238

Bradford M. M. (1976): A rapid and sensitive method for the quantitation of micogram quantities of protein utilizing the principle of protein-dye binding. Anal. Biochem. 72, 248-254 https://doi.org/10.1016/0003-2697(76)90527-3

Demiral T., Türkan I. (2005): Comparative lipid peroxidation antioxidant defense systems and proline content in roots of two rice cultivars differing in salt tolerance. Environ. Exp. Bot. 53, 247-257 https://doi.org/10.1016/j.envexpbot.2004.03.017 
Faria T., Wilkins D., Besford R. T., Vaz M., Pereira J. S., Chaves M. M. (1996): Growth at elevated carbon dioxide leads to down regulation of photosynthesis and altered response to high temperature in Quercus suber seedlings. J. Exp. Bot. 47, 1755-1761 https://doi.org/10.1093/jxb/47.11.1755

Foyer C. H., Halliwell B. (1976): The presence of glutathione and glutathione reductase in chloroplasts: a proposed role in ascorbic acid metabolism. Planta 133, 21-25 https://doi.org/10.1007/BF00386001

Foyer C. H., Noctor G. (2005): Oxidant and antioxidant signalling in plants: a re-evaluation of the concept of oxidative stress in a physiological context. Plant Cell Environ. 28, 1056-1071. https://doi.org/10.1111/j.1365-3040.2005.01327.x

Habib D., Chaudhary M. F., Zia M. (2013): The Study of Ascorbate Peroxidase Catalase and Peroxidase During In Vitro Regeneration of Argyrolobium roseum. Appl. Biochem. Biotechnol. 172, 1070-1084 https://doi.org/10.1007/s12010-013-0591-6

Holopainen T., Anttonen S., Wulff A., Palomäki V., Kärenlampi L. (1992): Comparative evaluation of the effects of gaseous pollutants acid deposition and mineral deficiencies: structural changes in the cells of forest plants. Agric. Ecosys. Environ. 42, 365-398 https://doi.org/10.1016/0167-8809(92)90009-Z

Kováčik J., Klejdus B., Hedbavny J., Bačkor M. (2009): Salicylic acid alleviates $\mathrm{NaCl}$-induced changes in the metabolism of Matricaria chamomilla plants. Ecotoxicology 18, 544-554 https://doi.org/10.1007/s10646-009-0312-7

Lascano H. R., Antonicelli E. G., Luna C. M., Melchiorre M. N., Gómez L. D., Racca R. W., Trippi V. S., Casano L. M. (2001): Antioxidant system response of different wheat cultivars under drought: field and in vitro studies Aust. J. Plant Physiol. 28, 1095-1102

Mozafar A., Oertli J. J. (1992): Uptake and transport of thiamin (vitamin B1) by barley and soybean. J. Plant Physiol. 436, $442-446$

Murashige T., Skoog F. (1962): A revised medium for rapid growth and bioassay with tobacco tissue culture. Physiol. Plant 15, 473-497 https://doi.org/10.1111/j.1399-3054.1962.tb08052.x

Nakano Y., Asada K. (1981): Hydrogen peroxide is scavenged by ascorbate-specific peroxidase in spinach chloroplasts. Plant Cell Physiol. 22, 867-880

Pine L., Hoffman P. S., Malcolm G. B., Benson R. F., Keen. M. G. (1984): Determination of catalase peroxidase and superoxide dismutase within the genus Legionella. J. Clin. Microbiol. 20, 421-429

Queirós F., Rodrigues J. A., Almeida J. M., Almeida D. P. F., Fidalgo F. (2011): Differential responses of the antioxidant defence system and ultrastructure in a saltadapted potato cell line. Plant Physiol. Biochem. 49, 1410-1419 https://doi.org/10.1016/j.plaphy.2011.09.020

Rehman R. U., Chaudhary M. F., Khawar K. M., Lu G., Mannan A., Zia M. (2014a): In vitro propagation of Caralluma tuberculata (N.E. Brown) and evaluation of antioxidant potential. Biologia 69, 1-9

https://doi.org/10.2478/s11756-013-0322-z
Rehman R. U., Zia M., Lu G., Chaudhary M. F. (2014b): Ascorbic acid and salicylic acid mitigate $\mathrm{NaCl}$ stress in Caralluma tuberculata calli. Appl. Biochem. Biotechnol. 173, 968-979 https://doi.org/10.1007/s12010-014-0890-6

Roldán-Arjona T., Ariza R. R. (2009): Repair and tolerance of oxidative DNA damage in plants. Mutat. Res-Rev. Mutat. Res. 681, 169-179 https://doi.org/10.1016/j.mrrev.2008.07.003

Senaratna T., Touchell D., Bunn T., Dixon K. (2000): Acetyl salicylic acid (Aspirin) and salicylic acid induce multiple stress tolerance in bean and tomato plants. Plant Growth Regul. 30, 157-161 https://doi.org/10.1023/A:1006386800974

Shirasu K., Nakajima H., Rajashekar K., Dixon R. A., Lamb C. (1997): Salicylic acid potentiates an agonist-dependent gain control that amplifies pathogen signal in the activation of defense mechanisms. Plant Cell 9, 261-270 https://doi.org/10.1105/tpc.9.2.261

Soikkeli S. (1981): A review of the structural effects of the air pollution on mesophyll tissue on the plants at the light and transmission electron microscope level. Savonia 4, 11-54

Sresty T. V. S., Rao K. V. M. (1999): Ultrastructural alterations in response to zinc and nickel stress in the root cells of pigeonpea. Environ. Exp. Bot. 41, 3-13 https://doi.org/10.1016/S0098-8472(98)00034-3

Szepesi A., Csiszar J., Bajkan S. Z., Gemes K., Horvath F., Erdei L., Deer A., Simon L. M., Tari I. (2005): Role of salicylic aicd pre-treatment on the acclimation of tomato plants to salt- and osmotic stress. Acta Biol. Szegediensis 49, 123-125

Türkan I. Bor M., Özdemir F., Koca H. (2005): Differential responses of lipid peroxidation and antioxidants in the leaves of drought-tolerant P. acutifolius Gray and drought-sensitive P. vulgaris L. subjected to polyethylene glycol mediated water stress. Plant Sci. 168, 223-331 https://doi.org/10.1016/j.plantsci.2004.07.032

Wang W. B., Kim Y. H., Lee H. S., Kim K. Y., Deng X. P., Kwak S. S. (2009): Analysis of antioxidant enzyme activity during germination of alfalfa under salt and drought stresses. Plant Physiol. Biochem. 47, 570-577 https://doi.org/10.1016/j.plaphy.2009.02.009

Xiong L., Zhu J. K. (2002): Molecular and genetic aspects of plant responses to osmotic stress. Plant Cell Environ. 25, 131-139 https://doi.org/10.1046/j.1365-3040.2002.00782.x

Yamane K., Kawasaki M., Taniguchi M., Miyake H. (2003): Differential effect of $\mathrm{NaCl}$ and polyethylene glycol on the ultrastructure of chloroplasts in rice seedlings. J. Plant Physiol. 160, 573-575 https://doi.org/10.1078/0176-1617-00948

Zhou W., Zhao D., Lin X. (1997): Effects of waterlogging on nitrogen accumulation and alleviation of waterlogging damage by application of nitrogen fertilizer and mixtalol in winter rape (Brassica napus L). J. Plant Growth Regul. 16, 47-53 https://doi.org/10.1007/PL00006974

Zhu J. K. (2001): Plant salt tolerance. Trends Plant Sci. 6, 66-71 https://doi.org/10.1016/S1360-1385(00)01838-0

Received: February 24, 2016

Final version accepted: April 15, 2016

First published online: February 20, 2017 